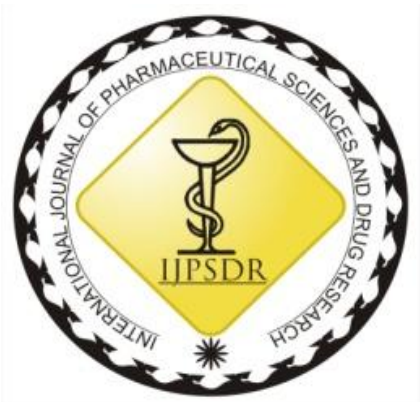

ISSN: 0975-248X

RESEARCH ARTICLE CODEN (USA): IJPSPP

$($ (c) $)$ EY-NC-SA

\title{
Curcumin Produces Protective Effects against Testicular Toxicity Induced By Cadmium in Albino Rats
}

\author{
Suman Sharma, Chetna Ahuja* \\ Department of Zoology and Environmental Sciences, Punjabi University, Patiala, Punjab, India
}

Copyright (c) 2019 Suman Sharma et al. This is an open access article distributed under the terms of the Creative Commons AttributionNonCommercial-ShareAlike 4.0 International License which allows others to remix, tweak, and build upon the work non-commercially, as long as the author is credited and the new creations are licensed under the identical terms.

\begin{abstract}
The purpose of our study was to evaluate the preventive effects of supplementation with curcumin (Cur) on Cadmium (Cd) induced testicular damage. Young male Wistar albino rats were divided into five groups; Control, Cd, Cur, $\mathrm{Cd}+\mathrm{Cur}$, pre-Cur+Cd. Rats were administered an acute dose of $\mathrm{CdCl}_{2}$ at a concentration of $50 \mathrm{mg} / \mathrm{kg}$ bw and Cur at $150 \mathrm{mg} / \mathrm{kg}$ bw for 15 days. The activities of the stress indicating enzymes (SOD, CAT) and MDA content as a result of LPO along with the total tissue protein and cholesterol were assessed in the testicular homogenate of rats. A significant reduction in the activities of SOD and CAT with parallel significant upsurge in MDA accompanied by a significant reduction in total tissue protein content and a significant rise in tissue cholesterol was observed in rat testes. Also, the reduction in the testicular weights along with a decline in testosterone concentration was detected. Further, Cur supplementation with Cd significantly upturned the Cd-induced variations in oxidative stress indicating enzymes and amended the testosterone levels, total testicular protein, and cholesterol content. Therefore, it can be concluded that Cur plays a protective role against testicular toxicity produced by a single dose of $\mathrm{CdCl}_{2}$.
\end{abstract}

Keywords: Testes, Cadmium, Curcumin, Oxidative Stress, SOD, CAT, Testosterone.

DOI: 10.25004/IJPSDR.2019.110517

Int. J. Pharm. Sci. Drug Res. 2019; 11(5): 255-262

*Corresponding author: Ms. Chetna Ahuja

Address: Department of Zoology and Environmental Sciences, Punjabi University, Patiala, Punjab, India

Tel.: +91-9855822068

E-mail $\bowtie$ : chetnaahuja.in@gmail.com

Relevant conflicts of interest/financial disclosures: The authors declare that the research was conducted in the absence of any commercial or financial relationships that could be construed as a potential conflict of interest.

Received: 16 August, 2019; Revised: 31 August, 2019; Accepted: 10 September, 2019; Published: 25 September, 2019

\section{INTRODUCTION}

Cadmium (Cd) is reflected as one of the supreme detrimental transition metal with an atomic weight of 48 and relative atomic mass of 112.41 . It possesses few specific features which make this metal suitable for several industrial applications such as production of $\mathrm{Ni}-\mathrm{Cd}$ batteries, dyes, varnishes, and others. It persists as an impurity in the ores of metals like $\mathrm{Zn}, \mathrm{Pb}$, and $\mathrm{Cu}$, etc. Industries such as metal refineries throw their perilous waste in the environment and people who live nearby these sources are affected from compromised health such as stomach pains, diarrhea, bone abnormalities, reproductive problems and at times, infertility. Cd can also disturb central nervous system, may evoke brain disorders and induce DNA destruction or cancer growth. ${ }^{[1]}$

The principal route of $\mathrm{Cd}$ exposure is its inhalation from industrial areas. Though, majority of the people are exposed to $\mathrm{Cd}$ by consuming $\mathrm{Cd}$ containing food and water. $\mathrm{Cd}$ exposure leads to $\mathrm{Cd}$ absorption in 
animals and humans. [2] When absorbed, $\mathrm{Cd}$ binds to metallothionein, creating a Cd-metallothionein complex which is transported largely to the liver and kidney through blood. [3] Absorbed Cd is expelled very slowly from the body, with an estimated half-life of 7-16 years. [4-5]

$\mathrm{Cd}$ is known to produce oxidative stress in living beings through numerous mechanisms like constraining the activities of primary antioxidant enzymes such as superoxide dismutase (SOD), catalase (CAT) ${ }^{[6]}$ and controlling free radicals' production such as ROS (reactive oxygen species) namely superoxide ion, hydroxyl radicals and hydrogen peroxide. [7] Furthermore, damage to cell organelles by generating ROS via oxidative stress is the key feature of $\mathrm{Cd}$ toxicity and when ROS counteracts with cellular biomolecules, generate lipid peroxidation which enhances protein damage of cellular membranes, DNA injury, altered gene expression and apoptosis. [8-9]

The incidents of decreased male fertility following $\mathrm{Cd}$ exposure have been confirmed both in humans and rodents. [10] $\mathrm{Cd}$ potentially affects reproductive mechanisms probably at every stage leading to disturbed reproduction and developments. [11] Since testes have a unique vascular system, it seems to be greatly affected by $\mathrm{Cd}$. [12-13]

Hypercholesterolemia marks alterations in sperm capacitation and acrosome reaction procedure. As a consequence, Leydig cells fail to perform their secretory action under hypercholesterolemic environment [14], or get modified to provide any hormonal support. [15-16] Furthermore, the spermatogenesis is an androgen dependent process, mainly testosterone [17], thus any variations in the concentration of this hormone would lead to transformed spermatogenesis.

Curcumin \{1,7-bis(4-hydroxy-3-methoxyphenyl)-1,6heptadiene-3,5-dione\} (diferuloylmethane), present in the rhizomes of Curcuma longa (Zingiberaceae), is the principle colouring agent of food in India. It owns several defensive properties including antioxidant [18-19], anti-inflammatory and anticancer activities. ${ }^{20]}$ Further, research has revealed curcumin (Cur) to be an influential scavenger of the hydroxyl radical and superoxide anion. [21] It is found to be effective against numerous disorders but the most significant property of Cur is that being an antioxidant and therapeutic agent with various constructive functions, it has no side effects. [22]

Therefore, this report addresses the changes in oxidative stress marker enzymes along with the alterations in total protein and cholesterol content in testes homogenate after acute $\mathrm{Cd}$ administration and whether the supplementation of Cur can rectify Cdinduced testicular oxidative injury in experimental rats.

\section{MATERIALS AND METHODS}

\section{Materials}

All biochemical reagents used in this study were of analytical grade, acquired from Himedia Laboratories
Pvt. Ltd. and Loba Chemie, Pvt. Ltd., Mumbai. $\mathrm{CdCl}_{2}$ was dissolved in distilled water and given to rats orally. Cur administered to rats by oral gavage in the form of aqueous suspension. [23]

\section{Animal Exposure}

Young albino male Wistar rats weighing $180 \pm 20 \mathrm{~g}$ were obtained from Disease Free Animal House, LUVAS, Hisar. Rats were kept at a constant temperature $\left(28 \pm 2^{\circ} \mathrm{C}\right)$, relative humidity $60 \pm 15 \%$ and 12 hours light/dark cycle. The animals were housed in plastic cages with bedding of soft chips. Two weeks prior to the onset of experiment, they were acclimatized to laboratory conditions and fed on the standard rat feed purchased from M/S Aashirwad Industries, Ltd., Chandigarh. Water was made available to them ad libitum. The experimental protocol was preceded by following the guidelines of the Committee for Purpose of Control and Supervision of Experiments on Animals (CPCSEA), India and Institutional Animal Ethical Committee approved the research.

\section{Experimental Design}

In this study, rats were equally divided into 5 groups $(n=5)$ and kept as designed protocol as follows:

Group 1 (Control): Rats were kept as control.

Group 2 (Cd): Rats were administered a single oral dose of $50 \mathrm{mg} / \mathrm{kg}$ bw of $\mathrm{CdCl}_{2}$ on day 1 and left for 15 days.

Group 3 (Cur): Rats were given an oral dose of 150 $\mathrm{mg} / \mathrm{kg}$ bw of Cur daily for 15 days and kept as a positive control.

Group 4 (Cd+Cur): Rats were given a single oral dose of $50 \mathrm{mg} / \mathrm{kg}$ bw of $\mathrm{CdCl}_{2}$ on day 1 and $150 \mathrm{mg} / \mathrm{kg}$ bw of Cur daily for the next 15 days and served as a posttreated group.

Group 5 (pre Cur+Cd): Rats were given an oral dose of $150 \mathrm{mg} / \mathrm{kg}$ bw of Cur daily for 15 days and $50 \mathrm{mg} / \mathrm{kg}$ bw of $\mathrm{CdCl}_{2}$ on the last day which served as a pretreated group.

\section{Hormonal Assay}

Approximately, $2 \mathrm{ml}$ of blood samples from each rat were collected in clean dry centrifuge tubes at the time of sacrifice. It was left for 20 minutes to clot at room temperature, centrifuged at $3000 \mathrm{rpm}$ for 5 minutes for separation of blood serum and quickly frozen at $-20^{\circ} \mathrm{C}$ for testosterone analysis. [24]

\section{Biochemical Analysis}

After sacrifice, testes from each rat were removed, cleaned of adipose tissue, blotted dry, weighed separately, homogenized in buffer ( $\mathrm{pH} 7.4)$, after which it was centrifuged at $3000 \mathrm{rpm}$ for 5 minutes. The collected supernatant was then processed for various biochemical investigations.

Lipid peroxidation (LPO) was quantified as malondialdehyde (MDA) according to the method described by Wilbur et al. [25]

Activities of antioxidant enzymes superoxide dismutase (SOD) and catalase (CAT) in testes homogenate were assessed by the methods specified by Das et al. and Aebi respectively. [26-27] 
Total testicular protein content was assessed by the method given by Lowry et al. [28]

Total cholesterol content in testes was estimated by the method of Zlatkis et al. [29]

\section{Statistical Analysis}

To compare the effects among various groups, data was subjected to one-way analysis of variance (ANOVA) followed by Post hoc Tukey HSD test. Also, Pearson's bivariate correlation analysis was done to the $\mathrm{Cd}$ exposed groups with several other variables using SPSS Statistics version 25 . The statistically significant values were represented by $p \leq 0.05, p \leq 0.001$ and $p \leq 0.0001$. The results are expressed as mean \pm S.D.
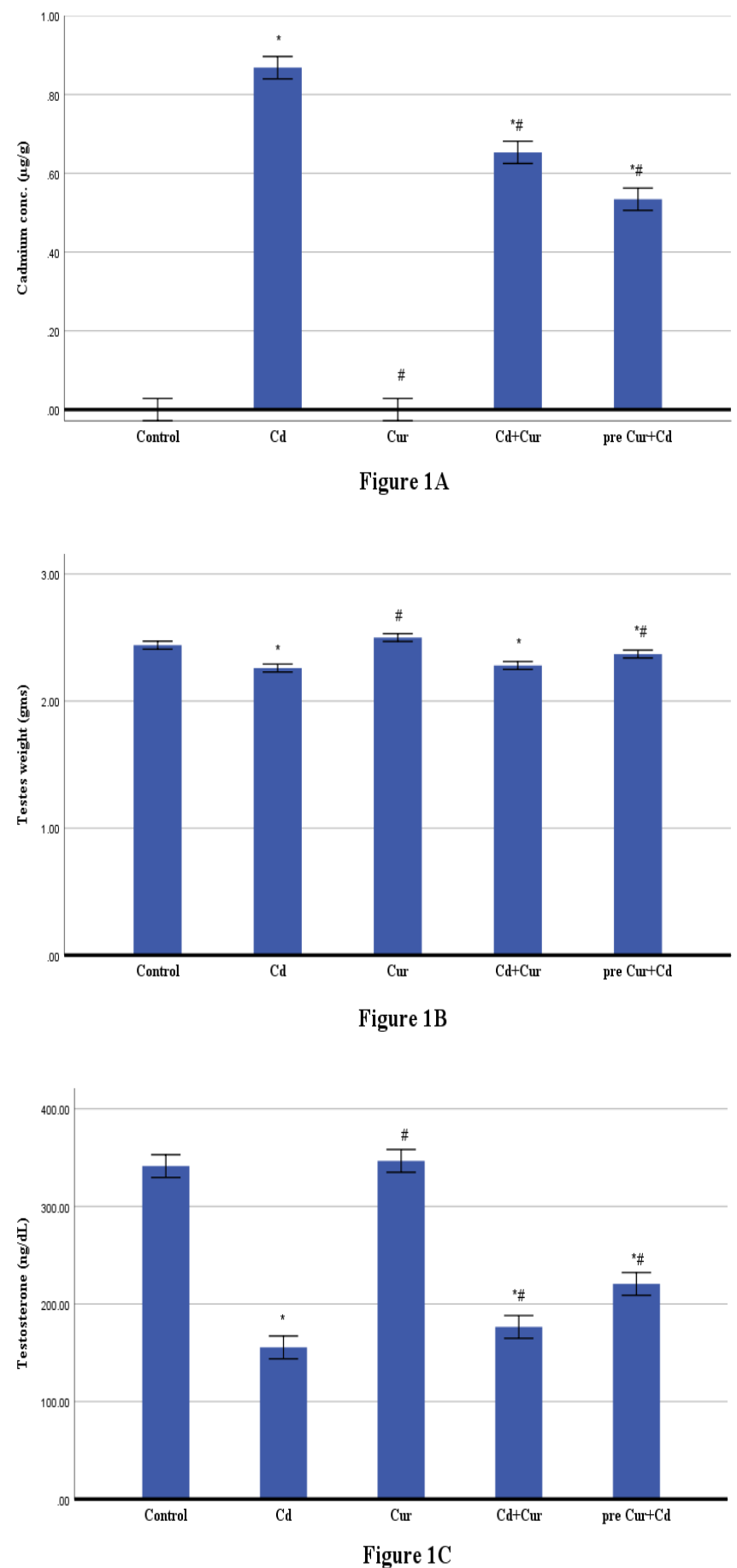

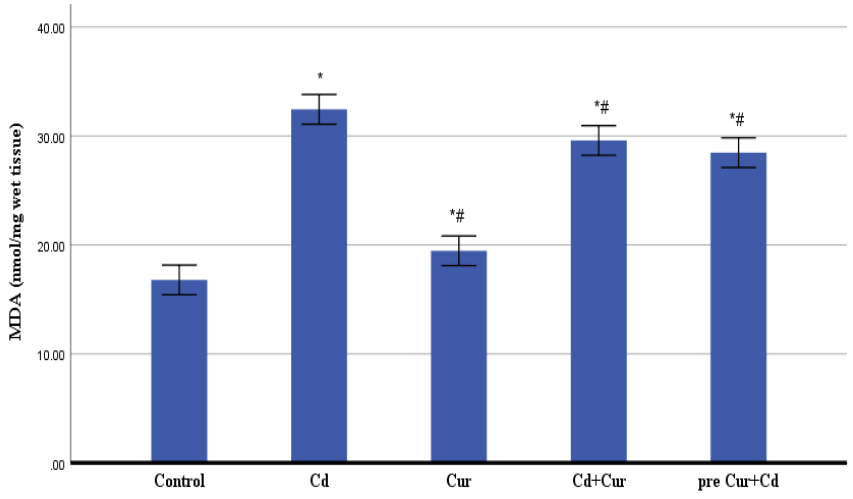

Figure 1D
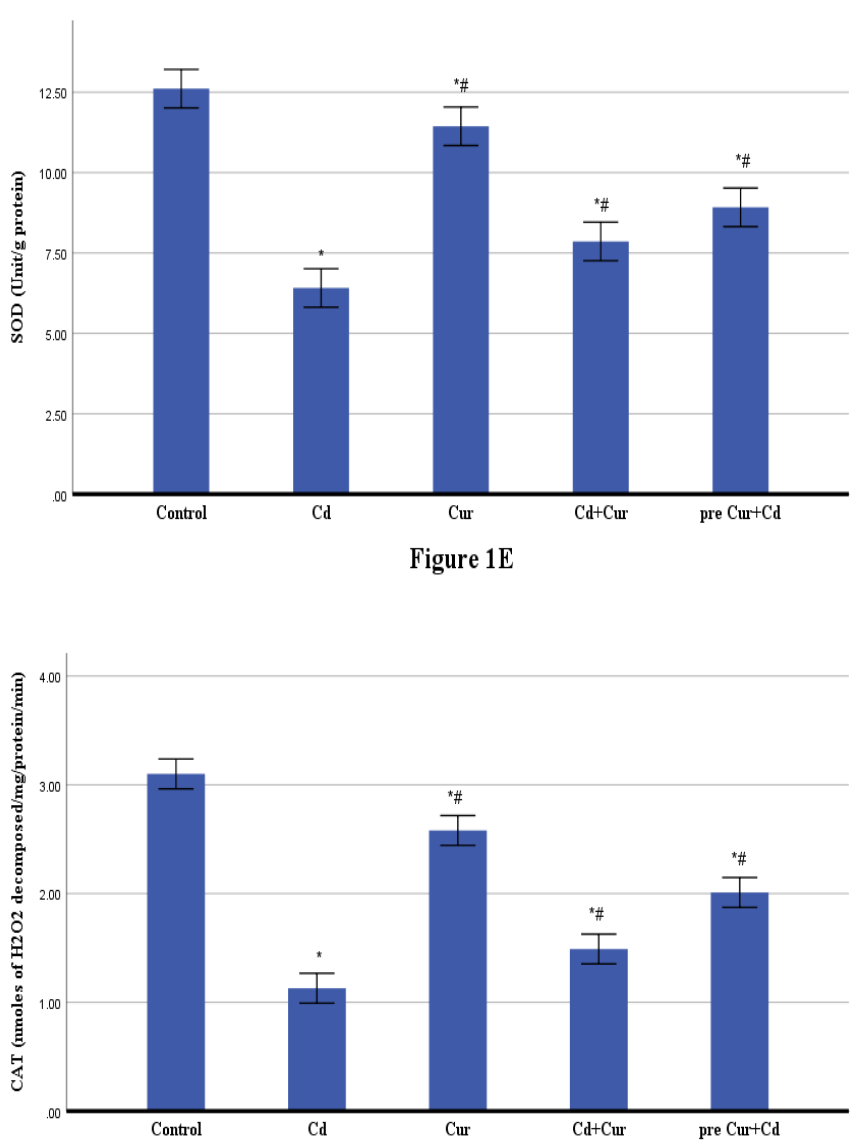

Figure 1F

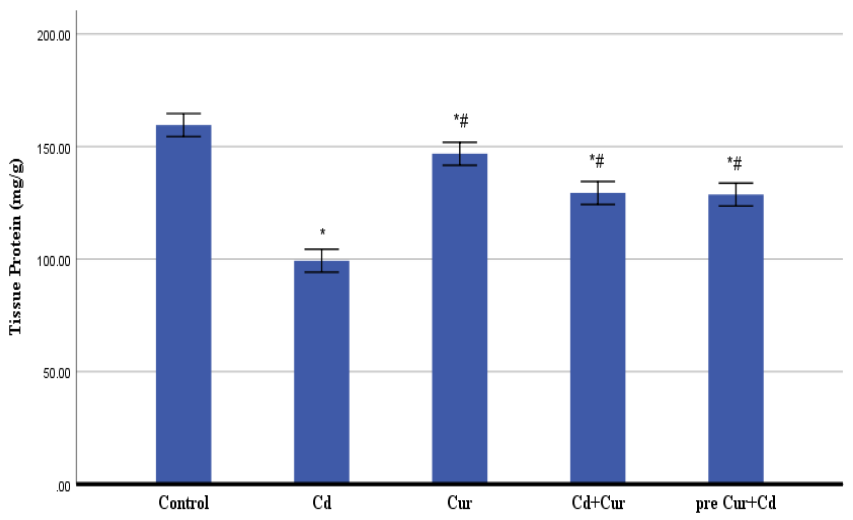

Figure 1G 


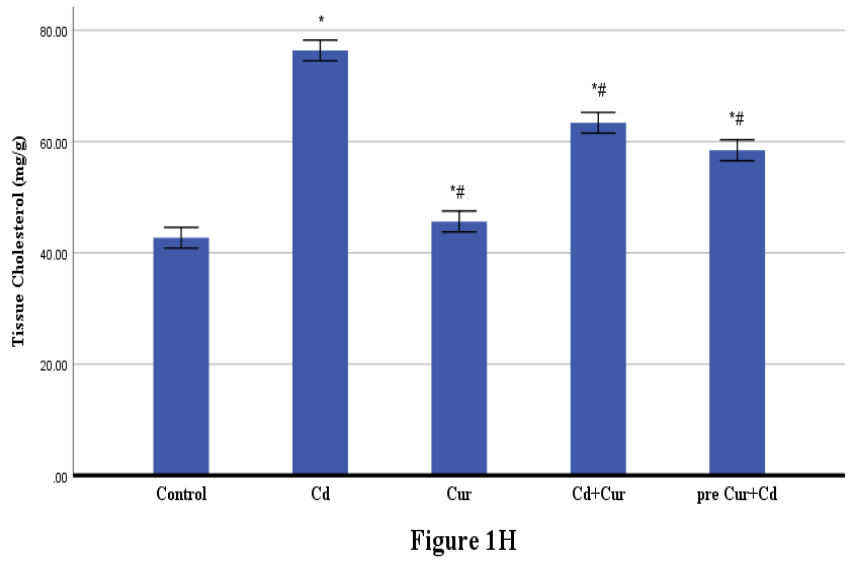

Fig. 1: Effects of acute exposure of $\mathrm{Cd}$ and Cur treatment on testes of rats: A. Cd concentration. B. Testicular weights. C. Plasma Testosterone levels. D. Lipid peroxidation (MDA) level. E. Superoxide dismutase (SOD) activity. F. Catalase (CAT) activity. G. Total protein content. H. Total cholesterol content. Values are presented as mean \pm S.D. for 5 animals/group. Differences were considered statistically significant for ${ }^{*} p \leq 0.05$ vs control; $\# p \leq 0.05$ vs $50 \mathrm{mg} / \mathrm{kg}$ Cd-exposed group G2. (S.D.= Standard Deviations; $p=$ probability)

\section{RESULTS}

Cd concentration in testes of experimental rats

The mean concentration of $\mathrm{Cd}$ in testes of experimental rats of different groups is presented by Figure 1A. The concentration of $\mathrm{Cd}$ in $\mathrm{Cd}$-exposed group $\mathrm{G} 2$, increased significantly $(p \leq 0.0001)$ as compared to control group G1. The positive control group G3 showed values similar to control. However, the mean Cd concentration in the Cur post-treated and pre-treated groups, G4 and G5, revealed significant $(p \leq 0.0001)$ higher values when compared to control rats G1 as well as Cd-treated rats G2.

Effect of Cur supplementation on body and organ weight of experimental rats following $\mathrm{Cd}$ administration

As calculated from the present study, the mean bodyweight of the experimental animals increased steadily in all the treated groups but less significant weight gain was observed in Cd-exposed rats G2 as compared to control G1. The mean weight of the testes in different groups is depicted in Figure 1B. The weight of the testes decreased significantly $(p \leq 0.0001)$ in Cdexposed group G2 compared to the control group G1. However, Cur treated G4 animals showed a nonsignificant $(p \leq 0.1)$ increase and G5 rats revealed a significant $(p \leq 0.001)$ increase in the testes weight when compared to Cd-treated rats G2. Further, a nonsignificant $(p>0.05)$ increase in testes weight was observed in positive control rats G3 compared to control rats G1.

Effect of Cur supplementation on mean testosterone levels in experimental rats following $\mathrm{Cd}$ administration

The effects of Cur supplementation on plasma levels of testosterone are presented in Figure 1C. The mean plasma levels of testosterone hormone decreased significantly $(p \leq 0.0001)$ in the $\mathrm{Cd}$ treated group G2 when compared with control group G1. Conversely, the Cur supplemented rats showed a statistically significant increase in G4 $(p \leq 0.01)$ and G5 $(p \leq 0.0001)$ rats in the mean plasma testosterone levels in comparison to Cd-intoxicated rats G2. Though, the mean levels of testosterone increased non-significantly $(p>0.5)$ in positive control group G3. Further, data suggest a significantly negative correlation $(\mathrm{r}=-0.927$; $p<0.0001$ ) between the mean $\mathrm{Cd}$ residue in the testes tissue and plasma levels of testosterone concentration (Fig. 2A).
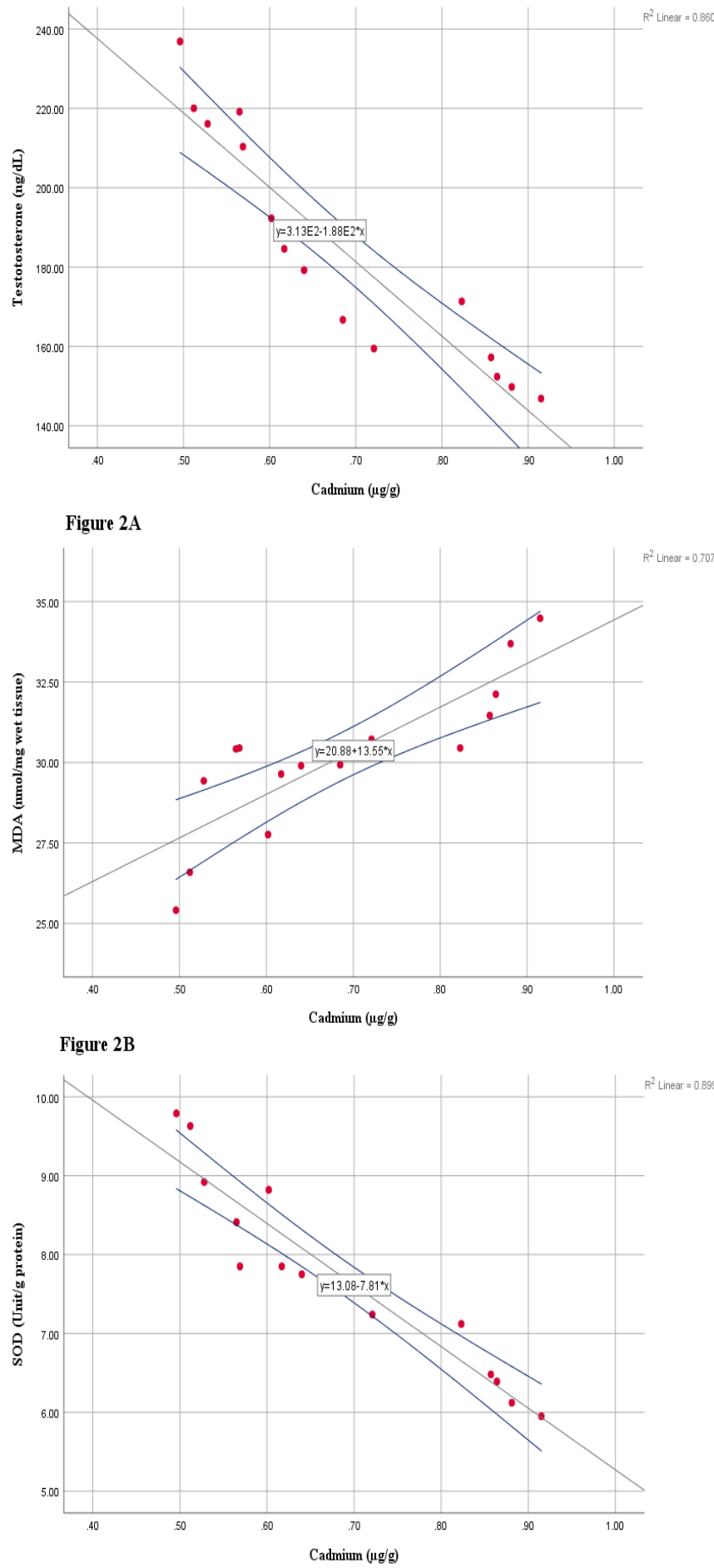

Figure 2C 

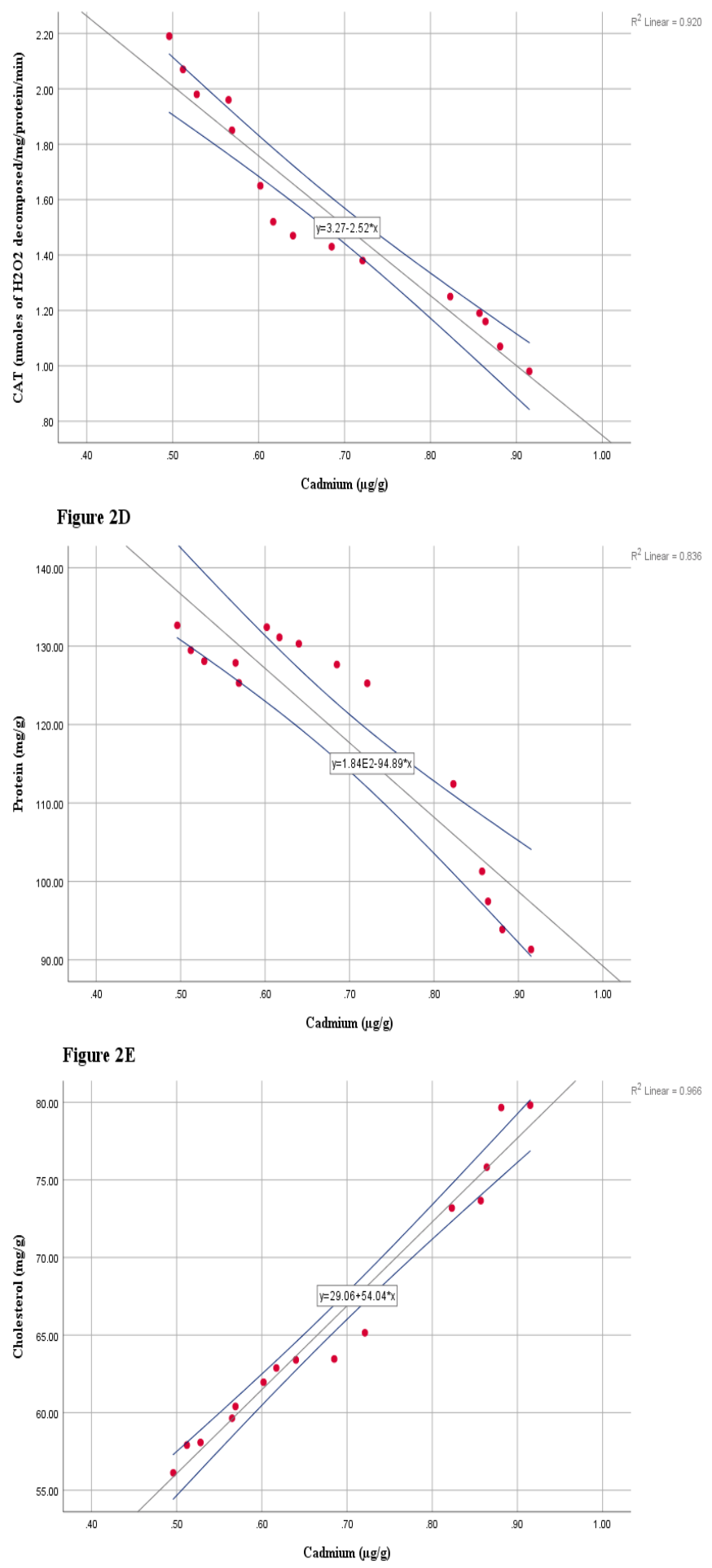

Figure 2F

Fig. 2: Pearson's bivariate correlation and simple linear regression analysis in $\mathrm{Cd}$ exposed groups $(\mathrm{Cd}, \mathrm{Cd}+\mathrm{Cur}$ and pre Cur+Cd). A Between tissue Cd concentration and plasma Testosterone levels. B. Between tissue Cd concentration and MDA content. C. Between tissue $\mathrm{Cd}$ concentration and SOD activity. D. Between tissue Cd concentration and CAT activity. E. Between tissue $\mathrm{Cd}$ concentration and Total tissue protein. F. Between tissue $\mathrm{Cd}$ concentration and Total tissue cholesterol. Differences were considered statistically significant for $p<0.05$.

Effect of Cur supplementation on malondialdehyde (MDA) level in experimental rats following $\mathrm{Cd}$ administration

To verify that Cd-induced stress upsurges lipid peroxidation in rat testis, the level of malondialdehyde
(MDA) determined is depicted in Figure 1D. The results showed that the testicular MDA level was significantly $(p \leq 0.0001)$ high in rats treated with $\mathrm{Cd}$ in comparison to control group. No significant changes were observed in testicular MDA levels in animals treated with Cur alone in comparison to the control group. Though, supplementation with Cur decreased the MDA level in G4 and G5 rats with a significant difference of $p \leq 0.05$ compared to Cd-exposed group G2. Figure $2 \mathrm{~B}$ shows a significant positive correlation $(\mathrm{r}=$ +0.841 ; $p<0.0001$ ) between mean $\mathrm{Cd}$ concentration in testes and tissue MDA level.

Effect of Cur supplementation on superoxide dismutase (SOD) activity in experimental rats following $\mathrm{Cd}$ administration

The specific activity of the SOD enzyme measured in testicular fractions from all the experimental rats is represented in Figure 1E. $\mathrm{Cd}$ exposure led to a significant $(p \leq 0.0001)$ decrease in SOD activity in G2 as compared to the control G1. Supplementation with Cur amended the damages induced by $\mathrm{Cd}$ exposure, triggering a significant increase in SOD activity in group G4 $(p \leq 0.05)$ and G5 $(p \leq 0.001)$ compared to Cd treated group G2. Notably, G5 rats exhibited greater recovery in comparison to G4 rats. Figure 2C displays that increase in tissue $\mathrm{Cd}$ content reduces the SOD activity suggesting SOD exhibited significant negative correlation $(r=-0.948 ; p<0.0001)$ with tissue $\mathrm{Cd}$ deposit. Effect of Cur supplementation on catalase (CAT) activity in experimental rats following $\mathrm{Cd}$ administration

Figure $1 \mathrm{~F}$ shows the specific activity of CAT in the treated groups. $\mathrm{Cd}$ exposure produced a significant $(p \leq 0.0001)$ reduction in CAT activity in G2 rats compared to control. Simultaneous administration of Cur adjusted the effects of $\mathrm{Cd}$ exposure by increasing the CAT activity significantly $(p \leq 0.001)$ in G4 and G5 rats in comparison to Cd-exposed G2 group. Also, the statistics suggest a significantly negative relationship ( $\mathrm{r}$ $=-0.959 ; p<0.0001$ ) between mean $\mathrm{Cd}$ content in testes tissue and CAT activity (Fig. 2D).

Effect of Cur supplementation on total tissue protein in experimental rats following $\mathrm{Cd}$ administration

The effects of Cur supplementation on testicular total protein content are presented in Figure 1G. In the present study, there is a significant $(p \leq 0.0001)$ decrease in testicular protein content in Cd-exposed rats G2 when compared to control rats G1. Cur coadministration revealed a significant $(p \leq 0.0001)$ increase in the protein content of G4 and G5 rats in comparison to Cd-intoxicated group G2. Also, data suggested significantly negative association $(\mathrm{r}=-0.914$; $p<0.0001$ ) between testicular mean $\mathrm{Cd}$ residue and total protein content (Fig. 2E).

Effect of Cur supplementation on total tissue cholesterol in experimental rats following $\mathrm{Cd}$ administration

In this study, the mean testicular cholesterol content was determined to know whether there is impaired 
steroidogenesis or not. The mean values of cholesterol content in testes homogenate is depicted (Fig. 1H), which shows that there was a significant $(p \leq 0.0001)$ increase in the mean cholesterol content in the testes of Cd-treated rats compared to control rats G1. Conversely, Cur treated rats G4 and G5 revealed significantly $(p \leq 0.0001)$ lower values of mean testes cholesterol content when compared to Cd-exposed rats G2. Simultaneously, data depicts a significant positive correlation $(\mathrm{r}=+0.983 ; p<0.0001)$ between mean testicular Cd content and tissue cholesterol (Fig. 2F).

\section{DISCUSSION}

$\mathrm{Cd}$ is considered to be an industrial pollutant and one of the deadliest heavy metal which has the ability to generate free radicals, resulting in oxidative stress by altering antioxidant balances in tissue. Cd exposure, acute as well as chronic, is associated with raised lipid peroxidation, the seriousness of which is governed by route, dose, and duration of $\mathrm{Cd}$ exposure. [30-31] $\mathrm{Cd}$ exhibits oxidative damage and due to its long retention in some critical tissues and it certainly may produce some severe pathological conditions. ${ }^{[32]}$ The outcomes of the present investigation have validated the ability of the $\mathrm{Cd}$ to produce oxidative stress in testes of rats through enhanced lipid peroxidation by single acute administration of $\mathrm{CdCl}_{2}$ at a concentration of $50 \mathrm{mg} / \mathrm{kg}$ bw. Further, there was a drop in the activities of testicular antioxidant enzymes SOD and CAT, which is considered to be natural antioxidant defense systems against ROS mediated tissue damage in several tissues as well as testes. ${ }^{[33]}$ The decline in the activities of SOD and CAT may be due to the simultaneous escalation in free radical's production in the testes exposed to $\mathrm{Cd}$. SOD exists in two isoforms, cytosolic SOD $(\mathrm{Cu} / \mathrm{Zn}$ SOD), the active sites of which is occupied by $\mathrm{Cu}$ and $\mathrm{Zn}$ and mitochondrial SOD (Mn/Zn-SOD) which comprises $\mathrm{Mn}$ and $\mathrm{Zn}$ at the active sites. The toxic effect of $\mathrm{Cd}$ could be the interaction of vital trace elements with $\mathrm{Cd}$, since $\mathrm{Cd}$ can lodge the $\mathrm{Zn}$ site in $\mathrm{Cu} / \mathrm{Zn}$-SOD enzyme, which in turn creates an inactive form of this enzyme $(\mathrm{Cu} / \mathrm{Cd}-\mathrm{SOD})$. [34] Several transition metals such as mercury, chromium, nickel, cadmium, and platinum are reported to increase ROS production which further grounds lipid peroxidation of the cell membrane, decrease glutathione and other antioxidant enzymes, cause apoptosis and ultimately participate in the oxidative damage of DNA. [35-36]

Similarly, reduction in CAT activity could be explained through the reduction in the amount of $\mathrm{H}_{2} \mathrm{O}_{2}$ as decreased SOD activity results in less conversion of $\mathrm{O}{ }^{-}$into $\mathrm{H}_{2} \mathrm{O}_{2}$ (substrate of CAT) or depletion of $\mathrm{H}_{2} \mathrm{O}_{2}$ by Fenton reactions. ${ }^{[37-38]}$ However, the SOD and CAT activities were increased significantly and the reduction in the lipid peroxidation was evidenced in Cur supplemented rats suggesting Cur to exhibit ameliorating effects against $\mathrm{CdCl}_{2}$ induced toxicity which could be due to its potential to improve the efflux and reduce the accumulation of $\mathrm{Cd}$ in testes.
In the present study, after acute exposure of rats to $\mathrm{Cd}$, the body weight gain, as well as the testicular weights, was significantly reduced. The reduction in body weight gain in these rats specifies general metabolic dysfunctions. Our results are in agreement with the study which shows that decrease in the amount of Sertoli cells or Leydig cells might be the reason of decline in testicular weight in the rats exposed to $\mathrm{Cd}$. [39] The production of free radicals by $\mathrm{CdCl}_{2}$ result in oxidative degradation of lipids, proteins and DNA causing atrophy to testes. ${ }^{[40-41]}$ However, Cd-mediated toxicity was significantly repressed by Cur and it kept the body weight gain and testicular weights nearly normal, demonstrating its defensive effects against $\mathrm{Cd}$ intoxication.

$\mathrm{Cd}$ exposure reduces productivity especially in males of both humans and rodents. [10] Many studies have revealed that male reproductive capacity in humans has depreciated during the past few years. [42] Transitional metals play a key role as an environmental factor which possibly disturbs the normal functioning of the male reproductive system. Toxicological studies have confirmed that numerous transition metals have the ability to gather in testes or epididymis damaging their reproductive and endocrine functions. ${ }^{[33]}$ In the present study, apart from body weight and antioxidant system changes, $\mathrm{Cd}$ also disrupted androgens where the serum testosterone levels were decreased significantly in the Cd-intoxicated rats. Studies revealed that $\mathrm{Cd}$ alters the testosterone production in isolated Leydig cells [44], signifying that steroidogenic disturbance in Leydig cells is expected to be a primary target of Cd toxicity as an EDC (Endocrine Disrupting Chemical). Furthermore, the reduction of testes weight is a principal indicator of likely alteration in androgen status [45], and lower doses of $\mathrm{Cd}$ may potentially induce testicular damage without pathologically affecting organs and considerably modifies the levels of several circulating steroid hormones such as testosterone. [46] Nevertheless, Cur administration prevented testosterone irregularities in $\mathrm{Cd}$-intoxicated rats suggesting protective effects of Cur. In parallel, it can be concluded that Cur prevented Cd-induced decrease in testes weight by normalizing serum testosterone level. [47]

Our results of the current study indicated that some of the $\mathrm{Cd}$-induced testicular damage may be mediated by a reduction in total testicular protein content, as evidenced in the rats exposed to $\mathrm{Cd}$. These variations possibly occur due to the changes in free amino acid and protein metabolism. [48] Besides, Cd-induced reactive oxygen species (ROS) leads to deterioration of tissue proteins by enhanced proteolytic activity, thereby decreasing the total tissue protein. [49]

Regarding the level of cholesterol, a significant increase was recorded in rats exposed to $\mathrm{Cd}$. Our results are in parallel with the earlier results where Cd potentially led to an increase in total cholesterol levels in the 
prostate gland and testes of rats. [50] The higher testicular cholesterol detected in this study might be attributed to the intra-gonadal alteration in lipid distribution; specially amplified displacement of lipid from the cell membranes within the testes or could be due to the increased prostatic discharge of cholesterol into the seminal plasma within the testes in reaction to the accumulation of $\mathrm{Cd}$ since cholesterol is generally released into the seminal plasma by the prostate gland as a biological event for the protection of sperms against oxidative stress. [51] Conversely, treatment with moderate doses of $150 \mathrm{mg} / \mathrm{kg}$ bw of Cur was found to be effective in plummeting the high cholesterol levels in the testes exhibiting the ameliorating effects of Cur. Similar results were previously obtained, where oral administration of Cur significantly reduced the high cholesterol levels. [52] These hypocholesterolemic effects of Cur can possibly be elucidated by its effect on the stimulation of bile acids and biliary cholesterol release and increased fecal elimination of bile acids and cholesterol. [53] In addition, the occurrence of high cholesterol levels in the testes might be a sign of decreased androgen production by the testes as evaluated in the present study. As testosterone is produced by Leydig cells, the function of which is impaired by high cholesterol levels. [13] The Cd-induced upsurge in cholesterol production inversely affects the normal Leydig cell function. Moreover, preconditions for the normal triggering of spermatogenesis are ideal Leydig cell function and normal testosterone production. [54]

The protective effects of Cur observed in this study could be attributed to its unique structure where two orthomethoxylated phenols and $\beta$-diketone moiety has the potential to quickly and competently quench lipid peroxyl radicals in advance before they possibly attack on lipid membranes, protecting the tissue or organ from ROS generated oxidative stress. [55-56] Moreover, studies suggested that Cur significantly decreases free radical's generation and increases the activities of antioxidant enzymes thereby exhibiting restorative effects. [57]

It can be concluded from this study that acute administration of $\mathrm{CdCl}_{2}$ leads to a significant decrease in the activities of SOD, CAT and increase in lipid peroxidation. Furthermore, reduction in serum testosterone level, decrease in testes mass, changes in total tissue protein and cholesterol content were also observed. All these alterations can be explained as a consequence and simultaneous increase in the free radicals' production in the testes of Cd-exposed rats which subsequently developed testicular injury and oxidative stress. However, Cd-exposed rats supplemented with Cur exhibited amelioration showing the defensive role of Cur against the testicular toxicity of $\mathrm{Cd}$ by blocking the free radical's generation thus stabilizing the cellular redox balance.

\section{ACKNOWLEDGEMENTS}

The authors would like to acknowledge the support and facilities provided by the Department of Zoology and Environmental Sciences, Punjabi University, Patiala to carry out the above research work.

\section{REFERENCES}

1. Singh P, Chaudhary S, Patni A, Sankhla V. Effect of cadmium chloride induced genotoxicity in bone marrow chromosomes of Swiss albino mice and subsequent protective effects of Emblica officinalis and vitamin C. J Herb Med Toxicol. 2007; 1(2):67-71.

2. IARC. Cadmium and cadmium compounds. IARC Monographs on the Evaluation of Carcinogenic Risks to Humans. 1993b; 58:119237.

3. Waalkes MP, Goering PL. Metallothionein and other cadmiumbinding proteins: recent developments. Chem Res Toxicol. 1990; 3(4): 281-288

4. Kjellstrom T, Nordberg GF. A kinetic model of cadmium metabolism in the human being. Environ Res. 1978; 16(1-3):248269.

5. Nordberg GF, Nogawa K, Nordberg M, Friedmann JM. Cadmium. In: Handbook on the Toxicology of Metals, Elsevier, Amsterdam, The Netherlands, 2007, pp. 445-486.

6. Casalino E, Calzaretti G, Sblano C, Landriscina C. Molecular inhibitory mechanisms of antioxidant enzymes in rat liver and kidney by cadmium. Toxicology. 2002; 179(1-2):37-50.

7. Liu J, Shen HM, Ong CN. Role of intracellular thiol depletion, mitochondrial dysfunction and reactive oxygen species in Salvia miltiorrhiza-induced apoptosis in human hepatoma $\mathrm{HepG}_{2}$ cells. Life Sci. 2001; 69(16):1833-1850.

8. Stohs SJ, Bagchi D, Hassoun E, Bagchi M. Oxidative mechanisms in the toxicity of chromium and cadmium ions. Journal of Environmental Pathology. J Environ Pathol Toxicol Oncol. 2000; 20(2):77-88

9. Wu X, Faqi AS, Yang J, Pang BP, Ding X, Jiang X, Chahoud I. 2Bromopropane induces DNA damage, impairs functional antioxidant cellular defenses, and enhances the lipid peroxidation process in primary cultures of rat Leydig cells. Reprod Toxicol. 2002; 16(4):379-384.

10. Benoff S, Jacob A, Hurley IR. Male infertility and environmental exposure to lead and cadmium. Hum Reprod Update. 2000; 6(2):107-121.

11. Thompson J, Bannigan J. Cadmium: toxic effects on the reproductive system and the embryo. Reprod Toxicol. 2008. 25(3):304-315.

12. Santos FW, Oro T, Zeni G, Rocha JBT, Nascimento PC, Nogueira CW. Cadmium induced testicular damage and its response to administration of succimer and diphenyl diselenide in mice. Toxicol Lett. 2004; 152(3):255-263.

13. Santos FW, Zeni G, Rocha JBT, Nascimento PC, Marques MS, Nogueira CW. Efficacy of 2,3-dimercapto-1-propanesulfonic acid (DMPS) and diphenyl diselenide on cadmium induced testicular damage in mice. Food Chem Toxicol. 2005; 43(12):1723-1730.

14. Shimamoto K, Sofikitis N. Effect of Hypercholesterolemia on Testicular Function and Sperm Physiology. Yonago Acta Medica. 1998; 41:23-29.

15. Hikim AP, Wang C, Leung A, Swerdloff RS. Involvement of apoptosis in the induction of germ cell degeneration in adult rats after gonadotropin-releasing hormone antagonist treatment. Endocrinology. 1995; 136(6):2770-2775.

16. Nandi S, Banerjee PP, Zirkin BR. Germ cell apoptosis in the testes of Sprague Dawley rats following testosterone withdrawal by ethane1,2-dimethanesulfonate administration: relationship to Fas? Biol Reprod. 1999; 61(1):70-75.

17. Sinha Hikim AP, Swerdloff RS. Hormonal and genetic control of germ cell apoptosis in the testis. Rev Reprod. 1999; 4(1):38-47.

18. Kunchandy E, Rao MNA. Oxygen radical scavenging activity of curcumin. Int J Pharm. 1990; 58(3):237-240.

19. Subramanian M, Sreejayan, Rao MN, Devasagayam TP, Singh BB. Diminution of singlet oxygen induced DNA-damage by curcumin and related antioxidants. Mutat Res. 1994; 311(2):249-255.

20. Srimal RC, Dhavan BN. Curcumin. Drugs Future. 1987; 12:331333 .

21. Unnikrishnan MK, Rao MNA. Curcumin inhibits nitrogen dioxide induced oxidation of hemoglobin. Mol Cell Biochem. 1995; $146(1): 35-37$. 
22. Sharma S, Ahuja C. Ameliorating Efficacy of Curcumin on Cadmium Induced Thyroid Dysfunction in Albino Rats. Int J Sci Res in Biological Sciences. 2019; 6(1):187-195.

23. Kamel R, Hashim AAA, Ali SAE. Palliative Effect of Curcumin on Stz-Induced Diabetes in Rats. Int J Pharm Pharm Sci. 2014; 6(2):558-563.

24. Chen A, Bookstein JJ, Meldrum DR. Diagnosis of a testosteronesecreting adrenal adenoma by selective venous catheterization. Fertil Steril. 1991; 55(6):1202-1203.

25. Wilbur KM, Bernheim F, Shapiro OW. The thiobarbituric acid reagent as a test for the oxidation of unsaturated fatty acids by various agents. Arch Biochem. 1949; 24(2):305-313.

26. Das K, Samanta L, Chainy GBN. A modified spectrophotometric assay of superoxide dismutase using nitrite formation by superoxide radicals. Indian J Biochem Biophys. 2000; 37(3):201-204

27. Aebi HE. Catalase. In: Methods of Enzymatic Analysis, Edn 3, Verlag Chemie, Weinhem, 1983, pp. 273-286.

28. Lowry $\mathrm{OH}$, Rosebrough NJ, Farr AL, Randall RJ. Protein measurement with the Folin phenol reagent. J Biol Chem. 1951; 193(1):265-275

29. Zlatkis A, Zak B, Boyle AJ. A new method for the direct determination of serum cholesterol. J Lab Clin Med. 1953; 41(3):486-492

30. Ognjanovic B, Zikic RV, Stajn A, Saicic ZS, Kostic MM, Petrovic VM. The Effects of Selenium on the Antioxidant Defense System in the Liver of Rats Exposed to Cadmium. Physiol Res. 1995; 44:293-300.

31. Sarkar S, Yadav P, Bhatnagar D. Cadmium-induced lipid peroxidation and the antioxidant system in rat erythrocytes: the role of antioxidants. J Trace Elem Med Biol. 1997;11(1):8-13.

32. Bagchi D, Bagchi M, Stohs SJ, Das DK, Ray SD, Kuszynski CA, Joshi SS, Pruess HG. Free radicals and grape seed proanthocyanidin extract: importance in human health and disease prevention. Toxicology. 2000; 148(2-3):187-197.

33. Adedara IA, Farombi EO. Induction of oxidative damage in the testes and spermatozoa and hematotoxicity in rats exposed to multiple doses of ethylene glycol monoethyl ether. Hum Exp Toxicol. 2010; 29(10):801-812.

34. Bauer R, Demeter I, Hasemann V, Johansen JT. Structural properties of the zinc site in $\mathrm{Cu}, \mathrm{Zn}$-superoxide dismutase; perturbed angular correlation of gamma ray spectroscopy on the $\mathrm{Cu}, 111 \mathrm{Cd}$ superoxide dismutase derivative. Biochem Biophys Res Commun. 1980; 94(4):1296-1302.

35. Li JL, Gao R, Li S, Wang JT, Tang ZX, Xu SW. Testicular toxicity induced by dietary cadmium in cocks and ameliorative effect by selenium. Biometals. 2010; 23(4):695-705

36. Othman MS, Nada A, Zaki HS, Abdel Moneim AE. Effect of Physalis peruviana L. on Cadmium-induced Testicular Toxicity in rats. Biol Trace Elem Res. 2014; 159(1-3):278-287.

37. Ognjanovic BI, Markovic SD, Ethordevic NZ, Trbojevic IS, Stajn AS, Saicic ZS. Cadmium-induced lipid peroxidation and changes in antioxidant defense system in the rat testes: protective role of coenzyme Q(10) and vitamin E. Reprod Toxicol. 2010; 29(2):191197.

38. Djukic MM, Jovanovic MD, Ninkovic M, Stevanovic I, Ilic K, Curcic M, Vekic J. Protective role of glutathione reductase in paraquat induced neurotoxicity. Chem Biol Interact. 2012; 199(2):74-86

39. Farombi EO, Adedara IA, Akinrinde SA, Ojo OO, Eboh AS. Protective effects of kolaviron and quercetin on cadmium-induced testicular damage and endocrine pathology in rats. Andrologia. 2012; 44(4):273-284.

40. Shen Y, Sangiah S. Na+, K(+)-ATPase, glutathione, and hydroxyl free radicals in cadmium chloride-induced testicular toxicity in mice. Arch Environ Contam Toxicol. 1995; 29(2):174-179.

41. Hussain H, Rodgers DA, Duhart HM, Ali SF. Mercuric chloride-induced reactive oxygen species and its effect on antioxidant enzymes in different regions of rat brain. J Environ Sci Health B. 1997; 32(3):395-409.

42. Carlsen E, Giwercman A, Keiding N, Skakkebaek NE. Evidence for decreasing quality of semen during past 50 years. BMJ. 1992; 305(6864):609-613.

43. Pandey R, Singh SP. Effects of molybdenum on fertility of male rats. Biometals. 2002; 15(1):65-72.

44. Laskey JW, Phelps PV. Effect of cadmium and other metal cation on in vitro Leydig cell testosterone production. Toxicol Appl Pharmacol. 1991; 108(2):296-306.

45. Biswas NM, Sen Gupta R, Chattopadhyay A, Choudhury GR, Sarkar M. Effect of atenolol on cadmium-induced testicular toxicity in male rats. Reprod Toxicol. 2001; 15(6):699-704.

46. Lafuente A, Gonzalez-Carracedo A, Romero A, Cano P, Esquifino AI. Cadmium exposure differentially modifies the circadian patterns of norepinephrine at the median eminence and plasma $\mathrm{LH}$ FSH and testosterone levels. Toxicol Lett. 2004; 146(2):175-182.

47. Chandra AK, Chatterjee A, Ghosh R, Sarkar M. Effect of curcumin on chromium-induced oxidative damage in male reproductive system. Environ Toxicol Pharmacol. 2007; 24(2):160-166.

48. Yousef MI, El-Demerdash FM, Radwan FM. Sodium arsenite induced biochemical perturbations in rats: ameliorating effect of curcumin. Food Chem Toxicol. 2008; 46(11):3506-3511.

49. Hussain T, Shukla GS, Chandra SV. Effects of Cadmium on Superoxide Dismutase and Lipid Peroxidation in Liver and Kidney of Growing Rats: In Vivo and In Vitro Studies. Pharmacol Toxicol 1987; 60:355-358.

50. Adaikpoh MA, Obi FO. Prevention of cadmium-induced alteration in rat testes and prostate lipid patterns by $\alpha$-tocopherol. Afr J Biochem Res. 2009; 3(10):321-325.

51. Sofikitis N, Miyagawa I. Secretary dysfunction of the male accessory genital gland due to prostate infections and fertility: A selected review of the literature. Jpn Fertil Steril. 1991; 36:690-699.

52. Soudamini KK, Unnikrishnan MC, Soni KB, Kuttan R. Inhibition of lipid peroxidation and cholesterol levels in mice by curcumin. Indian J Physiol Pharmacol. 1992; 36(4):239-243.

53. Srinivasan K, Sambaiah K. The effect of spices on cholesterol 7 alpha-hydroxylase activity and on serum and hepatic cholesterol levels in the rat. Int J Vitam Nutr Res. 1991; 61(4):364-369.

54. Hikim AP, Vera Y, Elhag RI, Lue Y, Cui YG, Pope V, Leung A, Atienza V, Wang C, Swerdloff RS. Mouse model of male germ cell apoptosis in response to a lack of hormonal stimulation. Indian J Exp Biol. 2005; 43(11):1048-1057.

55. Masuda T, Hidaka K, Shinohara A, Maekawa T, Takeda Y, Yamaguchi $\mathrm{H}$. Chemical studies on antioxidant mechanism of curcuminoid: analysis of radical reaction products from curcumin. J Agric Food Chem. 1999; 47(1):71-77.

56. Halliwell B, Gutteridge JMC. Free Radicals in Biology and Medicine. Edn 3, Oxford University Press Inc, New York, 2002, pp. $105-245$

57. Manikandan P, Sumitra M, Aishwarya S, Manohar BM, Lokanadam B, Puvanakrishnan R. Curcumin modulates free radical quenching in myocardial ischaemia in rats. Int $\mathrm{J}$ Biochem Cell Biol. 2004; 36(10):1967-1980. 